\title{
FORMULASI KODE ETIK PENDIDIK DALAM PERSPEKTIF PENDIDIKAN ISLAM
}

\author{
Moh. Farhan ${ }^{1}$
}

\begin{abstract}
Being Educator is an honour profession in Islam. It is an essensial factor in the education system. Thus a dignity and an authority of this profession have to be maintained by the educators. The way to keep the honour of this profession can be done by conducting ethical codes as a guidence to conduct activities as the educators.

In a modern era, an educator ethic has been formulated. However, it shows unoptimal to keep the educators' dignity. Thus, a solution is needed to solve the problem. Part of the solution from Islamic education scholars during Islamic education hystory is the genuin thinking of those scholars.

They have formulated the educator's ethics codes. From their thinking and ideas, there are three ethic codes that can be understood: The First: related to the obligation to have a good intention as the educator by improving a quality of "taqwa" to Allah SWT because teaching is a worship. The second: the educators have to keep their profession by improving the personality with a good character (Akhlak). The third, keep improving the educators' competences and professionalism.
\end{abstract}

Keywords: ethic code, teacher, Islam

\section{ABSTRAK}

Pendidik merupakan profesi yang sangat mulia dalam Islam. Keberadaannya menjadi salah satu faktor terpenting dalam sistem pendidikan. Sehingga marwah dan kewibawaan dari profesi ini harus senantiasa dijaga oleh para pendidik. Penjagaan atas kemuliaan tersebut dapat dilakukan dengan melaksanakan kode etik yang menjadi peganggan dalam melaksanakan atifitasnya sebagai pendidik.

Dalam era modern, kode etik pendidik telah dirumuskan. Tetapi tampaknya masih belum optimal untuk mampu menjaga marwah pendidik. Sehingga diperlukan solusi atas problem tersebut, diantaranya dari para pemikir pendidikan Islam.

Dalam lintasan sejarah pendidikan Islam, banyak ditemukan mutiara pemikiran para pemikir pendidikan Islam. Mereka telah memformulasikan dengan baik terkait dengan Kode Etik pendidik. Dari pemikiran para tokoh pendidikan Islam, dapat dipahami bahwa kode etik pendidik secara garis

Dosen Program Studi Pendidikan Agama Islam (PAI) Jurusan Tarbiyah Fakultas Agama Islam (FAI) Universitas Islam Sultan Agung (UNISSULA) Semarang 
besar ada tiga hal utama, pertama, terkait dengan keharusan meluruskan niat sebagai pendidik dengan senantiasa meningkatkan kualitas ketakwaan kepada Allah karena mendidik merupakan ibadah. Kedua, harus senantiasa menjaga profesinya dengan memperbaiki kepribadian dengan akhlak yang mulia. Dan ketiga, senantiasa meningkatkan profesionalitasnya sebagai pendidik.

\section{Kata Kunci : Kode Etik, pendidik, Islam.}

\section{A. PENDAhULUAN}

Pendidik merupakan salah satu komponen terpenting dalam sistem pendidikan. ia dianggap sebagai motor penggerak laju atau tidaknya suatu pendidikan. Ibarat sebuah mobil, pendidik merupakan pengemudinya yang bertugas mengarahkan dan menuntun laju tidaknya mobil tersebut. Kemanapun arah laju pendidikan, ditentukan oleh pendidik sebagai pengemudi dan pengatur perjalanan mobil tersebut. Maka tidak heran jika di negara-negara Timur sejak zaman dahulu menempatkan pendidik pada posisi yang mulia. Di India misalkan, pendidik dianggap sebagai manusia suci dan juga sakti. Di Jepang pendidik diidentikan dengan nama sensei, artinya yang lebih dahulu lahir (lebih tua). (Daradjat, 2012: 39).

Keberadaan pendidik dianggap sebagai orang yang bertanggungjawab terhadap perkembangan potensi dari peserta didiknya. Hal ini bisa dilaksanakan melalui berbagai upaya serius dan sistematis untuk mengembangkan kemampuan peseserta didiknya baik dalam bidang kognitif, psikomotorik, maupun psikomotoriknya(Tafsir, 1992: 74-75). Dalam dimensi ini menunjukan bahwa arti vital keberadaan pendidik sebagai salah satu bagian yang paling bertanggungjawab terhadap peserta didiknya untuk dapat mencapai tujuan pendidikan tersebut.

Para pakar juga sepakat menyebutkan bahwa pendidik merupakan orang yang memiliki tingkat kedewasaan sehingga mampu memberikan pengarahan dan bimbingan kepada peserta didiknya sehingga bertambah tingkat kedewasaannya. Kedewasaan disini bukan hanya diartikan bertambah usia peserta didik, namun lebih diartikan sebagai peningkatan dari aspek psikologis, emosional, dan intelegen daripada peserta didik.

Dalam paradigma Jawa, keberadaan pendidik diidentikan dengan sebutan guru yang bermakna digugu lan ditiru (Mujib, 2014: 90) Sebagai seorang yang digugu maksudnya adalah, setiap ucapan yang disampaikan oleh guru dapat dijadikan referensi dalam bertindak serta berisi nasihat kebaikan dan sesuai dengan nilai kebenaran. Hal ini dikarenakan tingkat intelegensi guru dianggap melebihi dari masyarakat pada umumnya. Sedangkan makna ditiru menunjukan bahwa setiap perangai yang dilaksanakan oleh guru mampu dijadikan sebagai uswah dalam kehidupan sehari-hari karena mereka 
dianggap melaksanakan sesuatu berdasaran keilmuan yang dimilikinya. Hal ini menunjukan bahwa sakralitas posisi sebagai seorang pendidik benar-benar nampak dalam komunitas masyarakat sebagai bentuk apresiasi atas jasa dan kedudukan mereka.

Pantas saja jika muncul kata bijak tentang pendidik dari Ki Hajar Dewantara, yaitu Ing ngarsa sung tuladha, Ing madya mangun karsa, tut wuri handayani. Dalam hal ini dapat dimaknai bahwa pendidik harus bisa menjadi contoh ketika berada di depan, mampu membangun kerjasama ketika berada ditengah, dan mampu memberikan dorongan ketika berada dibelakang (Vita, 2016: 9-10). Terlihat dengan jelas bahwa pendidik memiliki tugas dan tanggungjawab yang mulia dalam rangka untuk meningkatkan kualitas masyarakat. Oleh sebab itulah, seorang pendidik memiliki tugas dan amanah yang tidak ringan dalam rangka untuk mencetak generasi yang bagus. Hal ini sebetulnya bisa dicapai dengan cara memberikan keteladanan yang baik dalam rangka menjalankan pengabdian profesinya.

Namun demikian kini posisi kesakralan pendidik semakin mengalami pergeseran. Hal itu dapat dipahami dari berbagai problematika yang muncul serta perkembangan zaman yang semakin tidak terbendung. Peran pendidik semakin mengalami perubahan yang signifikan akibat adanya kemajuan dalam berbagai bidang sehingga mengarahkan mereka terjebak pada posisi hedonis, materialis, bahkan pragmatis (Nata, 2016: 56). Akibatnya marwah sebagai pendidik mulai terkikis, seakan mereka mulai mengalami disorientasi atas profesi mulianya tersebut.

Kondisi yang demikian mengharuskan adanya upaya serius untuk mengembalikan ruh sakralitas pendidik. Salah satu upaya yang bisa ditempuh dengan mendesain formulasi kode etik pendidik khususnya dalam perspektif Islam yang dapat digunakan sebagai pegangan bagi mereka dalam rangka menjalankan amanah sucinya tersebut. Hal ini dikarenakan dalam konteks Islam, ternyata banyak Ulama di masa lampau yang telah menuangkan gagasan cemerlangnya untuk memberikan formulasi terkait dengan hal-hal yang harus dilaksanakan pendidik dalam rangka menjalankan tugas sucinya sebagai insan yang membimbing peserta didik.

\section{B. MAKNA KODE ETIK PENDIDIK}

Untuk mengetahui maksud kode etik pendidik secara komprehensif, tentu saja perlu dilihat kembali makna istilah kode etik dan pendidik. Secara etimologis, istilah kode etik berasal dari dua kata yaitu 'kode' dan 'etik'. Kata kode berasal dari bahasa Prancis yang bermakna norma atau aturan. Sedangkan kata etik berasal dari kata etiquette yang bermakna tata atau tingkah laku (Kunarto, 1997: 322). 
Dari definisi tersebut dapat dipahami bahwa kode etik merupakan seperangkat pedoman berperilaku yang berisi norma-norma yang harus diaati oleh suatu profesi tertentu. Dengan mentaati seperangkat norma-norma tersebut akan bisa menjadikan keberhasilan dapat menjalankan profesinya dengan baik.

Dalam pendidikan Islam, kata pendidik memiliki persamaan dengan murobbi, mu'allim, mu'addib, dan mursyid. Menurut Ahmad Tafsir (1992: 7475), pendidik dimaknai dengan mereka yang memiliki tanggungjawab terhadap perkembangan peserta didiknya yang dilakukan dengan mengembangkan seluruh kemampuan yang dimiliki oleh peserta didik, baik itu terkait dengan aspek cipta (kognitif), rasa (afektif), dan karsa (psikomotorik). Menurut Abuddin Nata, bahwa dalam Al Quran istilah pendidik ada beberapa macam. Diantaranya diidentikan dengan istilah ulama, al-Rasikhuna fi al-Ilm, ahlDzikr, al-Mudzakki, Ulul al-bab, muwa'idz al waidzin, ulin nuha (Nata, 2016: 103). Istilah tersebut dianggap memiliki korelasi yang sigifikan dengan profesi pendidik.

Dalam hal ini kode etik pendidik merupakan aturan-aturan nilai dan juga norma yang harus dijadikan pegangan oleh pendidik dalam rangka melaksanakan tugasnya. Sehingga dengan menjalankan kode etik tersebut maka pendidik akan dapat mencapai tujuan dari profesinya.

Hal ini berimplikasi apabila pendidik melaksanakan pelanggaran atau penyelewengan terhadap kode etik, secara otomatis mereka akan mendapatkan sanksi baik secara moral maupun administratif. Oleh sebab itu, pendidik dituntut untuk senantiasa menjaga marwah dari profesinya dengan memegang secara teguh pada norma-norma dalam kode etik. Ketika hal tersebut dilaksanakan maka tugas pendidik akan bisa tercapai dengan baik.

\section{MENGURAI KOMPETENSI PENDIDIK}

Posisi sebagai pendidik sangat istimewa, khususnya dalam agama Islam. Hal ini bisa dilihat dari banyaknya sumber otoritatif Islam yang mengunggulkan profesi pendidik. Pendidik dianggap sebagai suatu profesi yang tinggi karena melaksanakan tugas pembimbingan kepada peserta didik sehingga diharapkan mereka akan memiliki kualitas keilmuan dan keimanan yang baik.

Tingginya derajat pendidik dalam Islam telah diisyaratkan oleh Nabi Muhammad SAW dalam hadisnya: "Jadilah kamu seorang pendidik, pelajar, pendengar, atau pecinta, namun jangan sampai engkau menjadi golongan kelima (selain itu), sehingga engkau akan menjadi rusak". Dari hadis tersebut menunjukan bahwa posisi yang paling utama adalah seorang pendidik. Hal ini bisa dipahami karena seorang pendidik dianggap memiliki tingkat kedewasaan yang lebih baik dalam keilmuan maupun aplikatifnya. 
Kedudukan pendidikan yang demikian mulia diperkuat dengan penghargaan berupa strata sosial yang tinggi dalam masyarakat. Posisi pendidik di masyarakat selalu diberikan penghormatan karena kualitas keilmuan dan pengamalan atas ilmu yang dimiliki. Hal ini merupakan bentuk apresiasi besar dari masyarakat terhadap profesi pendidik. Sehingga tugas sebagai pendidik merupakan profesi yang sangat mulia. Oleh sebab itu, pendidik harus memiliki berbagai kompetensi yang melekat pada dirinya supaya sukses dalam rangka menjalankan tugasnya sebagai pendidik.

Kompetensi pendidik diartikan seperangkat hal yang harus dimiliki pendidik dalam rangka untuk menjalankan tugas dan profesinya dengan baik. Dalam hal ini kompetensi sangat diperlukan untuk menopang profesionalitas sebagai pendidik. Dimana pendidik merupakan profesi yang sangat berpengaruh terhadap maju tidaknya suatu bangsa karena memiliki tugas utama untuk mencerdaskan kehidupan bangsa sehingga memiliki tingkat keimanan, ketaqwaan, dan akhlak mulia, serta keilmuan sebagaimana diamanahkan oleh tujuan pendidikan nasional.

Menurut Muhamin, pendidik dalam konteks Islam harus memiliki tiga kompetensi:

1) Kompetensi Personal Religius; dalam hal ini pendidik sebagai individu personal harus memiliki sifat-sifat yang melekat padanya. Baik terkait dengan kejujuran, tanggungjawab, amanah, atau objektifitas. Dimana hal itu diharapkan bisa menunjang terhadap profesionalisme keguruannya.

2) Kompetensi sosial religious; dalam hal ini pendidik harus memiliki sifat sosial yang baik, karena sebagai makhluk sosial dia tidak bisa hidup sendiri. Pendidik harus mampu berinteraksi dan berkomunikasi secara baik kepada peserta didiknya ketika terjadi proses interaksi belajar. Selain itu pendidik harus mampu menjalin hubungan yang baik kepada teman profesinya (baca: pendidik) dan orangtua peserta didik. Hal ini sangat penting karena pendidik senantiasa memberikan dorongan kepada peserta didiknya untuk terus melaksanakan kegiatan belajar. Kemampuan mereka untuk bisa berkomunikasi dengan baik menjadi hal yang mutlak harus dimiliki pendidik.

3) Kompetensi profesional religius; dalam hal ini pendidik harus meiliki kemampuan yang berhubungan dengan tingkat profesionalitas pendidik dalam rangka menjalankan tugas pokoknya sebagai pengajar. Meliputi berbagai kemampuan untuk merencanakan, melaksanakan, mengorganisasi, dan mengevaluasi pembelajaran.

Dari tiga kompetensi di atas, terlihat bahwa Muhaimin ingin menekankan pentingnya religiusitas dalam diri pendidik. Artinya bahwa untuk sukses dalam mengemban amanah sebagai pendidik, mereka harus 
memiliki tingkat religiusitas yang tinggi sehingga apa yang dicontohkan oleh Rasulullah sebagai pendidik yang paripurna, menerapkan konsep uswah hasanah dalam pembelajarannya akan bisa tercapai dengan baik. Karena religiusitas dalam diri pendidik menjadi faktor penentu untuk menunjang kesusksesan dalam mengemban amanah profesinya.

Menurut Undang-undang bahwa profesi pendidik harus memiliki 4 (empat) kompetensi.:

1) Kompetensi Paedagogik, dalam hal ini berhubungan erat dengan kemampuan pendidik dalam rangka untuk melaksanakan proses pembelajaran dengan baik. Tugas pokok pendidik yaitu untuk mengarahkan dan mendidik peserta didiknya supaya menjadi pribadi yang lebih dewasa.

2) Kompetensi professional, pendidik harus memiliki profesionalitas dalam mengemban amanahnya. Profesionalisme ini bisa terwujud salah satunya dengan linearitas antara keilmuan pendidik dengan materi yang diajarkan. Dan selalu mengambangkan kemampuannya dalam rangka untuk mengemban amanah sebagai pendidik.

3) Kompetensi kepribadian, guru harus memiliki pribadi yang baik. Tidak heran apabila pendidik dianggap memiliki tingkat kedewasaan yang lebih tinggi dibandingkan dengan peserta didiknya. Hal ini menunjukan bahwa profesi pendidik harus sudah dipersiaopkan dengan matang, dia harus mampu membangun jati dirinya sebagai pribadi yang santun, soleh, dan juga berkararketr. Sehingga diharapkan bisa mengatarkan peserta didiknya menjadi insan kamil.

4) Kompetensi sosial, pendidik harus memiliki sikap dan kemampuan untuk berkomunikasi secara baik dengan orang. Komunikasi yang terjalin itu harus diwujudkan dengan cara yang baik. Dimana komunikasi yang dibangun bukan hanya dalam ranah lisan namun juga tulisan. Oleh karena itu pendidik dituntut harus mampu berkomunikasi dengan baik, karena dengan komunikasi itulah dia akan bisa membangun sinergisitas dengan profesinya.

Dari apa yang telah disampaikan oleh para pemikir pendidikan Islam, dapat dipahami bahwa profesi pendidik merupakan profesi yang harus dipersiapkan dengan matang. Artinya mereka yang berada pada ranah pendidik harus memiliki kompetensi yang selalu diasah dalam setiap aktifitasnya sehingga akan mampu menjadi pendidik yang professional serta mampu mengatarkan peserta didiknya menuju tingkat keilmuan, kedewasaan, dan ketaqwaan yang lebih tinggi. 
Syekh Athiyah al-Abrasyi mengutip pernyataan dari Imam al-Syawki bahwa dalam syairnya yang terkenal, dinyatakan: "berdiri dan hormatilah guru dan juga berilah penghargaan kepada seorang guru karena hampir saja di ibaratkan dia adalah seorang rasul".

Dalam menjalankan tugas profesionalitasnya sebagai pendidik, seorang pendidik diharuskan mempunyai seperangkat kompetensi yang wajib melekat dalam diri pendidik tersebut. Tingkat kompetensi yang di miliki oleh pendidik sangat ditentukan oleh keinginan dari pendidik untuk senantiasa maju ke depan memperbaiki kualitas dirinya sebagai pendidik.

Kompetensi pendidik biasa dimaknai sebagai sejumlah pengetahuan, keterampilan yang harus dimiliki oleh profesi pendidik untuk memudahkan dalam melaksanakan tugas dan fungsi untuk mewujudkan tujuan dari pendidikan. Artinya bahwa setiap pendidik harus memiliki kompetensi ini karena memang dengannya diharapkan tugas dan tanggungjawab sebagai pendidik akan dapat dilaksanakan dengan baik.

Menurut Abdul Mujib, bahwa pendidik dalam perspektif pendidikan Islam harus memiliki kompetensi sebagai berikut: 1). Harus memahami keislaman yang komprehensif khususnya yang terkait dengan bidang tugasnya; 2). Harus menguasai strategi pembelajaran (mencakup metode, materi, dan evaluasi); 3). Harus memiliki penguasaan ilmu dan pengetahuan kependidikan; 4). Memahami prinsip-prinsip dalam rangka melakukan penafsiran terhadap penelitian bidang kependidikan, sehingga bisa dikembangkan untuk kemajuan pendidikan Islam pada masa yang akan datang; 5). Harus memiliki penguasaan terhadap kemajuan informasi (Mujib, 2014: 94-95).

\section{FOMULASI KODE ETIK PENDIDIK DALAM ISLAM}

Keberadaan kode etik pendidik dalam pendidikan sangatlah diperlukan. Hal ini tidak lain karena memang kode etik tersebut berisi norma-norma yang bisa digunakan sebagai pegangan para pendidik dalam rangka untuk menjalankan profesinya, baik ketika berada di sekolah maupun masyarakat (Soetjipto, 2007: 30). Ia menjadi norma yang mengikat kesakralan suatu profesi sehingga diharapkan bahwa ketika menjalankan tugasnya tidak melampaui batasan yang dilarang dalam profesinya.

Dalam sejarah pemikiran para Ulama dalam pendidikan Islam, banyak ditemukan khazanah mutiara pemikiran dalam ranah kode etik pendidik. Dimana kode etik ini di rumuskan oleh para Ulama pemikir pendidikan Islam untuk dijadikan pegangan bagi pendidik pada waktu itu. Namun demikian, bukan berarti sudah tidak relevan dengan masa sekarang, tetap saja pemikiran para Ulama tersebut dapat diaplikasikan oleh para pendidik di era sekarang ini. Diharapkan ketika pendidik menerapkan norm-norma tersebut akan dapat 
menjalankan profesinya dengan baik. Sehingga marwah pendidik akan tetap bisa terjaga dalam masyarakat, karena mereka memegang kode etik pendidik dalam perspektif Islam.

Ada hal menarik terkait dengan Kode Etik Pendidik dalam Islam. Karena dia dapat dijadikan sebagai pegangan norma yang harus dipatuhi oleh setiap pendidik. Hal ini menunjukan bahwa posisi pendidik begitu sangat penting sehingga ulama memberikan batasan kode etik lebih banyak dibandingkan dengan peserta didiknya. Al-Ghazali menyatakan bahwa :

1. Pendidik harus memiliki rasa senang terhadap peserta didiknya. Sebaiknya peserta didik dikasih sayangi sebagaimana anaknya sendiri. Ini merupakan kunci sukses bagi pendidik ketika ingin sukses dalam mengajar.

2. Pendidik haruslah meneladi sifat-sifat Rasulullah. Hal ini karena memang pendidik merupakan orang yang menjalankan ajaran Rasulullah baik dalam tugas dakwah maupun tugas mendidik. Pendidik dalam konteks ini harus memiliki keikhlasan sebagaimana para nabi ketika berdakwah kepada umatnya.

3. Pendidik hendaklah bisa memberikan nasihat apapun untuk kemaslahatan peserta didik.

4. Pendidik sebagai teladan bagi peserta didik, hendaknya senantiasa memberi perintah kepada peserta didiknya untuk meninggalkan akhlak tercela.

Dalam kitab Muraqi al-Ubudiyah fi Syarkh al-Bidayah al-Hidayah (Al-Bantani, tth: 88) yang ditulis oleh Ulama Jawa kharismatik, yaitu Syekh Muhammad Nawawi al-Jawi al-Bantani menyebutkan bahwa pendidik memiliki kode etik diantaranya:

1. Harus siap untuk menerima problematika peserta didik dengan hati yang lapang, serta diiringi sikap yang tabah.

2. Harus senantiasa memiliki sikap santun dan juga penyayang, sebagaimana dalam QS. Ali-Imron: 159.

3. Harus mampu menjaga kewibawaan dan marwah profesi pendidik dalam setiap aktifitas kehidupannya, baik dalam konteks tindakan maupun ucapan.

4. Harus bisa menjauhi dari sikap sombong kepada siapapun sebagaimana QS. Al-Najm: 32.

5. Harus bisa memiliki sikap rendah hati kepada kelompok masyarakat disekitarnya QS. Al-Hijr: 88.

6. Harus meniadakan setiap kegiatan yang tidak memiliki nilai guna dan sia-sia.

7. Harus memiliki sikap lembah lembuh khususnya terhadap peserta didik yang memiliki tingkat IQ yang lebih rendah dari peserta didik 
lainnya, kemudian dia harus berkenan untuk memberikan pembinaan secara maksimal kepadanya.

8. Harus bisa meninggalkan sikap marah ketika menghadapi problematika yang ada, khususnya dalam konteks tugas keguruan.

9. Harus berkenan untuk senantiasa memperbaiki kualitas sikap dari peserta didiknya, dan juka bersikap lemah lembut khususnya kepada peserta didik yang kurang lancar dalam hal berbicara.

10. Harus bisa meninggalkan sikap yang menakutkan bagi peserta didiknya, khususnya ketika peserta didik belum memiliki pemahaman yang komprehensif dalam suatu materi pelajaran.

11. Harus senantiasa memberikan perhatian terhadap segala macam pertanyaan yang diajukan oleh peserta didiknya, sekalipun pertanyaan tersebut memiliki kualitas yang rendah dan juga tidak tertalu sesuai dengan materi pembelajaran yang sedang diajarkan.

12. Harus siap untuk menerima kebenaran yang disampaikan oleh peserta didiknya.

13. Harus senantiasa mengedepankan kebenaran dalam setiap proses pembelajaran, sekalipun kebenaran tersebut berasal dari peserta didiknya.

14. Harus dapat mencegah peserta didiknya dari belajar ilmu yang tidak baik (berbahaya) sesuai dengan inspirasi QS. Al-Baqarah : 195.

15. Harus senantiasa menanamkan sifat ikhlas kepada peserta didiknya, serta berusaha secara maksimal dalam rangka mencari keilmuan terkait dengan hal bisa disampaikan kepada peserta didiknya supaya memiliki tingkat taqarrub kepada Allah SWT. Hal ini sesuai dengan QS. Al-Bayyinah: 5.

16. Harus mampu mencegah dan mengarahkan peserta didiknya untuk mempelajari ilmu fardu kifayah sebelum ilmu fardu 'ain.

17. Harus bisa mengaktualisasikan informasi yang disampaikan kepada peserta didiknya, sesuai dengan QS. Al-Baqarah : 44 dan QS. AsShaf: 2-3.

Tentu saja ketika setiap pendidik memegang kode etik yang dirumuskan tersebut, profesi suci mereka akan bisa terjaga marwah nya dengan baik. Selain itu dalam rangka menjalankan tugas dan fungsinya, para pendidik akan mengalami kemudahan dalam rangka untuk mewujudkan tugas mulia dari amanah pendidikan atas mereka.

Hal tersebut sesuai dengan pendapat Muhammad Athiyah al-Abrasyi, sebagaimana dikutip oleh Abdul Mujib dan Jusuf Mudzakkir dalam Ilmu Pendidikan Islam (2014: 99-100), dijelaskan bahwa setiap guru hendaknya memegang kode etik dalam perspektif pendidikan Islam sebagaimana berikut ini: 
1. Seorang pendidik diharuskan memiliki sifat kebapakan sebelum dia menjadi seorang pendidik, sehingga diharapkan bahwa pendidik bisa menyayangi dan mendidik secara totalitas terhadap peserta didiknya sebagaimana dia menyayangi anaknya sendiri.

2. Harus terwujud komunikasi yang aktif antara pendidik dan peserta didik. Dimana pola komunikasi yang terjadi bisa berada dalam kegiatan proses belajar mengajar.

3. Harus bisa mengetahui kondisi dan kemampuan dari peserta didiknya. Dalam konteks ini bahwa pemberian materi pembelajaran yang diberikan oleh pendidik harus disesuaikan dengan kadar kemampuan yang dimiliki oleh peserta didik.

4. Harus bisa memberikan perhatian secara menyeluruh kepada seluruh peserta didiknya, dalam hal ini tidak boleh bagi seorang pendidik hanya memperhatikan sebagian dari peserta didiknya.

5. Harus memiliki sifat adil, suci dan juga kesempurnaan, baik dalam ucapan maupun tindakan.

6. Harus memiliki rasa ikhlas dalam rangka menjalankan tugas profesinya sebagai seorang pendidik. Dia tidak diperkenankan menuntut berbagai macam hal diluar dari haknya.

7. Harus mampu mengkorelasikan antara satu materi dengan materi lainnya. Dalam hal ini pendidik harus bisa menerapkan pola integrated curriculum dalam aktifitas pembelajaran.

8. Harus mampu membekali peserta didiknya dengan ilmu pengetahuan yang dapat digunakan dimasa yang akan datang, karena peserta didik akan berhadapan dengan masa yang berbeda dengan masa sekarang. Hal ini sebagaimana disampaikan oleh Ali bin Abi Tholib bahwa "Didiklah anak-anak kalian, karena sesungguhnya dia akan hidup pada zaman yang berbeda dengan zaman kalian".

9. Diharapkan memiliki kesehatan jasmani dan rohani, serta memiliki kepribadian yang kuat, bertanggungjawab, dan dapat mengatasi berbagai macam problematika yang dihadapi oleh peserta didiknya. Selain itu dia harus memiliki suatu perencanaan yang matang dalam rangka untuk menatap masa depan dengan sungguh-sunguh atas apa yang akan dilaksanakan.

Sedangkan menurut Ibnu Jama'ah, sebagaimana yang dikutip oleh Abdul Mujib dari Abd al-Amir Syams al-Din, menyatakan bahwa pendidik hendaknya memiliki tiga macam etika yaitu: 1) Etika yang berkaitan dirinya pribadi, 2) Etika yang berkaitan dengan peserta didiknya, dan 3) Etika dalam kegiatan proses belajar mengajar. (Mujib, 2014: 99-100) 
Pemikir pendidikan Islam kontemporer, Zakiah Daradjat (2012: 4044) menyatakan bahwa secara umum pendidik harus mampu memenuhi tanggungjawabnya dengan baik. Untuk dapat menjalankan tugas dan fungsinya dengan baik paling tidak ada 4 (empat) hal yang harus diupayakan oleh pendidik.

Pertama pendidik disyaratkan harus memiliki tingkat keimanan dan ketakwaan yang tinggi terhadap Allah SWT. Hal ini menjadi penting karena memang iman dan takwa menjadi pondasi utama bagi pendidik untuk mampu mengantarkan peserta didiknya menjadi insan kamil. Tentu saja untuk mewujudkan peserta didik menjadi insan kamil yang dekat dengan Allah SWT, haruslah dimulai dari faktor pendidik yang memiliki tingkat keimanan dan ketakwaan yang tinggi disisi Allah SWT.

Kedua, pendidik disyaratkan harus memiliki kapasitas keilmuan yang mumpuni. Hal tersebut dapat dipahami karena memang pendidik memiliki tugas utama untuk melaksanakan bimbingan keilmuan terhadap peserta didiknya.

Ketiga, pendidik disyaratkan harus memiliki kesehatan jasmani. Hal tersebut dianggap sebagai salah satu faktor penentu dalam rangka sukses menjalankan profesinya.

Keempat, pendidik disyaratkan harus memiliki perilaku yang terpuji (akhlak al-karimah) sesuai dengan profesinya. Hal ini dapat dicerminkan dari munculnya rasa senang dengan profesi yang dijalankan, bersikap adil kepada setiap peserta didiknya, senantiasa berlaku sabar, memiliki kewibawaan, senantiasa gembira, bersifat humanistik, mampu bekerjasama dengan sesama guru, dan dapat bekerja sama dengan masyarakat. Dari pendapat para ahli di atas, dapat diketahui bahwa ternyata pendidik harus melaksanakan kode etik profesinya.

\section{E. PENUTUP}

Dari uraian yang sudah penulis paparkan di atas, dapat dipahami bahwa ternyata dalam Islam kode etik bagi pendidik telah dirumuskan oleh para Ulama pendidikan Islam. Terkait dengan hal tersebut seharusnya bagi setiap pendidik wajib melaksanakan kode etik tersebut dengan penuh kesungguhan dalam setiap aktifitas pendidikannya. Dengan melaksanakan kode etik pendidik, diharapkan marwah para pendidik akan dapat terjaga dengan baik. Sehingga benar-benar pendidikan Islam akan bisa menjadi jawaban atas problematika yang melilit kehidupan masyarakat.

Sesuai dengan pemikiran para pakar pendidikan Islam, diketahui bahwa pendidik harus senantiasa menjaga profesinya dengan memperbaiki pribadinya dengan akhlak yang mulia, meluruskan niatnya dalam rangka untuk menjalankan tugas sucinya, dan senantiasa meningkatkan profesionalitasnya sebagai pendidik. 
Dengan kegiatan tersebut diharapkan pendidik akan mampu melaksanakan profesinya secara optimal. Memang profesi ini sangat suci dalam agama, karena berdimensi dunia dan ukhrowi. Dengan menjalankan profesionalitasnya dengan baik akan bisa mendorong terwujudnya pendidikan yang berkualitas.

\section{DAFTAR PUSTAKA}

Al-Bantani, Muhammad Nawawi al-Jawi, tth, Muraqi al-Ubudiyah fi Syarkh al-Bidayah al-Hidayah, Bandung: al-Ma'arif

Athiyah, Al-Abrasy, Muhammad, 1970, Dasar-dasar Pokok Pendidikan Islam, Terj. H. Bustami A. Gani, Jakarta: Bulan Bintang

Daradjat, Zakiah, 2012, Ilmu Pendidikan Islam, Jakarta: Bumi Aksara

Mujib, Abdul dan Jusuf Mudzakkir, 2014, Ilmu Pendidikan Islam, Jakarta: Kencana

Muhaimin dan Abdul Mujib, 1993, Pemikiran dan Pendidikan Islam: Kajian Filosofi dan Kerangka Dasar Operasionalisasinya, Bandung: Trigenda Karya

Nata, Abuddin, 2016, Inovasi Pendidikan Islam, Jakarta: Salemba Diniyah , 2016, Pendidikan dalam Persepektif al-Qur'an, Jakarta: Prenadamedia Group

PP Nomor 74 Tahun 2008 Tentang Guru

Syamsu al-Din, Abd al-Amir, 1984, al-Madzhab al-Tarbawi 'Inda Ibn Jama'ah, Beirut: Dar Iqra'

Tafsir, Ahmad, 1992, Ilmu Pendidikan dalam Perspektif Islam, Bandung: Remaja Rosdakarya

UU Nomor 14 Tahun 2005 Tentang Guru dan Dosen

Vita, Yan, 2016, Pengembangan Kinerja \& Profesionalisme Guru: Teori dan Contoh Pengembangan Keprofesian secara Berkelanjutan dan Penilaian Kinerja Guru, Semarang: RaSAIL Media Group 